\title{
An Estimation of Market Size for Microfinance: Study on the Urban Microentrepreneurs in Selangor, Malaysia
}

\author{
Salwana Hassan ${ }^{1}$, Md. Mahmudul Alam ${ }^{2} \&$ Rashidah Abdul Rahman ${ }^{3}$ \\ 1 Accounting Research Institute / Faculty of Business Management, Universiti Teknologi \\ MARA, Shah Alam, Malaysia \\ ${ }^{2}$ School of Economics, Finance \& Banking, College of Business, Universiti Utara Malaysia, \\ Kedah, Malaysia \\ ${ }^{3}$ Faculty of Administration \& Economics, King Abdul Aziz University, Jeddah, Saudi Arabia
}

Correspondence: Md. Mahmudul Alam, School of Economics, Finance \& Banking, College of Business, Universiti Utara Malaysia, Kedah, Malaysia. E-mail: rony000@gmail.com

\section{Citation Reference:}

Hassan, S., Alam, M.M., Rahman, R.A. 2015. An Estimation of Market Size for Microfinance: Study on the Urban Microentrepreneurs in Selangor, Malaysia. Asian Social Science, Vol. 11 (27), pp. 269-274. [Online Link]

This is a pre-publication copy.

The published article is copyrighted by the publisher of the journal. 


\title{
An Estimation of Market Size for Microfinance: Study on the Urban Microentrepreneurs in Selangor, Malaysia
}

\begin{abstract}
Malaysia is a fast growing developing country where majority of the people are Muslim. Due to the religious bindings, Muslim prefers Shariah compliant Islamic credits instead of conventional interest based credits. At the same time, non-Muslims can also consider Shariah compliant Islamic credit because it is considered as the ethical credit. However, still many microentrepreneurs are not receiving the Shariah compliant Islamic microfinance products because they have negative perceptions about the credit and interest (riba). Therefore, this study aims to assess the demand for microfinance among the microentrepreneurs in the State of Selangor, Malaysia and thus, determine the potential market size. Data of the study were collected based on a questionnaire survey from 550 microentrepreneurs from the urban areas of Selangor. It was found that only 12.2 per cent of them received microfinance from various microfinance institutions and banks. However, the study found that still there is potential for microfinance borrowing with around 55,000-128,000 microenterprises in Selangor, Malaysia. Therefore, Islamic microfinance institutions should try to expand their market size by promoting these potential microfinance borrowers among the existing microentrepreneurs.
\end{abstract}

Keywords: microfinance, Islamic microfinance, microentrepreneur, microenterprise, SME, Malaysia, Shariah

JEL Classification: G21, N85, O10

\section{Introduction}

Microfinance promotes economic and social empowerment of the poor and low income people. Business capital is the most difficult to obtain for the working poor, the poor, and the unemployed, thus if they lack savings or other forms of collateral, they will find that business loans are inaccessible. In the absence of financial services, poor people often have to rely on informal financial sources such as friends and family as well as moneylenders. Microfinance institutions (MFIs) also provide financial services such as loans and insurance targeted at low-income clients or those who are not bankable.

With a population of more than 28 million of which 60 per cent are Muslims, Malaysia is a large consumer market for micro-entrepreneurial development. Here, MFIs can either be in the form of non-governmental organisations (NGO), government agencies, charitable organisations, banking institutions, non-banking organisations or a combination of these. Microfinance services that are being offered are mostly Shariah compliant products based on Qard Hassan (benevolent loan), Ijarah, and Bai Al-Inah (sale and buy-back agreement) contracts. The two largest Islamic microfinance institutions in Malaysia, Amanah Ikhtiar Malaysia and Bank Rakyat, have shown good progress over the years by availing financial access to the Muslim poor that would not jeopardize their religious beliefs towards the prohibition of interest (Dar et al., 2012; Kamaluddin et al., 2015; Alam, Said, \& Hassan, 2015).

The funding of some of the MFIs depends a lot on donations and subsidies from other parties; therefore, their existence and sustainability really depends on the outreach. The more they can reach their clients, the more impressive their performances will be (Osotimehin \& Akinlabi, 2011). Previous studies have indicated that demand for microfinance is based on outreach that is the ability of MFIs to reach out to the clients (Cheng, 2007; Molla et al. 2008; Molla \& Alam, 2008, 2011; Alam \& Molla, 2012a, b).

Ayayi \& Yusupov (2012) claimed that it is an overly simplistic projection to assume that every poor individual needs a loan. Some poor people choose not to borrow to start a business as they do not want to be in debt (Reinke, 2004). Standard and Poor's Microfinance Rating Methodology Working Group estimated that about 50 per cent of the poor worldwide are potentially eligible for microcredit/ microfinance to initiate microbusinesses which was also supported by a study done by the CGAP on microentrepreneurs in Latin America (Ayayi \& Yusupov, 2012; Anand \& Rosenberg, 2008; Gazy, 2005).

Given this information, there is a need to estimate the potential market size for microfinance. Therefore, the objective of this study is to assess the demand and the potential market size for microfinance among the microentrepreneurs in Malaysia.

\section{Methodology}

The study collected questionnaire survey data from 550 microentrepreneurs in several selected towns or urban areas in Selangor, Malaysia. Data were projected through the use of the 1-5 point Likert-scale, denoted by 
strongly disagree (1) to strongly agree (5). The sample included both recipients and non-recipients of any form of microfinance from four selected areas, they are Shah Alam / Kelang (32 per cent), Subang Jaya / Petaling Jaya (23 per cent), Selayang / Ampang Jaya (14 per cent), and Sepang / Kajang (31 per cent). Data were collected in September, 2013.

\section{Findings and Discussions}

\subsection{Demographic Characteristics of Microentrepreneurs}

In general, the respondents are almost equally distributed between both genders (Table 1). About 40.9 per cent of the respondents are in the $31-45$ age groups. The majority ( 83.2 per cent) of the respondents are Malays, followed by 8.0 per cent Chinese, 7.1 per cent Indians, and 1.8 per cent from other ethnicities. More than 46 per cent of the respondents are running their businesses in shops, followed by the mobile night or day market; about 11 per cent of them are running home-based businesses, and another 6 per cent do not have a specific business location; they could be running an online business. More than 70 per cent of the respondents run their small scaled businesses on a full-time basis and 22 per cent of them on a part-time basis.

Table 1. Demographic characteristics of the sample microentrepreneurs

\begin{tabular}{cccc}
\hline & Demographic Variables & No of Respondents & $(\%)$ \\
\hline Gender & Male & 262 & 47.9 \\
& Female & 285 & 52.1 \\
Race & Malay & 455 & 83.2 \\
& Chinese & 44 & 8 \\
Age & Indian & 38 & 6.9 \\
& Others & 10 & 1.8 \\
& Below 18 & 4 & 0.7 \\
& $18-30$ & 146 & 26.7 \\
Location of business & $31-45$ & 224 & 41 \\
& $46-60$ & 165 & 30.2 \\
& Over 60 & 8 & 1.5 \\
& Market (permanent) & 89 & 16.3 \\
& Shop & 255 & 46.6 \\
Type of business & Night / Day market (mobile) & 111 & 20.3 \\
& Home & 59 & 10.8 \\
& Not applicable & 33 & 6 \\
\hline
\end{tabular}

\subsection{Characteristics of Microenterprises}

The size of the microenterprises is very small as reflected from the size of their current business capital (Table 2). Around 31 per cent of them are operating with a current capital of below RM1,000. A very small group (8 per cent) has a capital of above RM15,000. The size of capital is also related to their ability to obtain finance. Based on the survey, all of them mentioned that they are the owners who operate and manage the business. Moreover, on average, the microentrepreneurs have only 2 full-time employees.

Table 2. Business characteristics of the sample microenterprises

\begin{tabular}{|c|c|c|c|}
\hline \multicolumn{2}{|c|}{ Business Status } & \multirow{2}{*}{$\begin{array}{c}\text { No of Respondents } \\
168\end{array}$} & \multirow{2}{*}{$\begin{array}{c}\%) \\
31\end{array}$} \\
\hline Size of Business Capital & Below RM1000 & & \\
\hline & RM1000-5000 & 209 & 38 \\
\hline \multirow{5}{*}{ Monthly Income } & RM5001-15000 & 128 & 23 \\
\hline & More than RM15000 & 42 & 8 \\
\hline & Less than RM1500 & 72 & 13.2 \\
\hline & RM1501-2500 & 149 & 27.2 \\
\hline & RM2501-3500 & 0154 & 28.2 \\
\hline
\end{tabular}




\begin{tabular}{lccc} 
& RM3501-5000 & 104 & 19 \\
Nature of Business & More than RM5000 & 68 & 12.4 \\
& Trading & 291 & 53.2 \\
& Manufacturing & 95 & 17.4 \\
& Services & 134 & 24.5 \\
& agriculture & 3 & 0.5 \\
Construction & Others & 2 & 4 \\
Sources of Financing* & Self-financing & 22 & 82.2 \\
& Family / Friends & 453 & 23.6 \\
& Bank \& Microfinance loan & 129 & 12.2 \\
& Money lender & 67 & 4 \\
& Suppliers & 22 & 3.1 \\
& Ar-Rahnu / Pawnshop & 17 & 2.9 \\
\hline
\end{tabular}

* Borrowers have multiple sourcing of financing

Most of the entrepreneurs run their businesses on a full-time basis and earn RM1,500 to RM5,000 monthly. Some of them (12.4 per cent) earn more than RM5,000 per month. Hence, quite a number of the entrepreneurs (13.2 per cent) who earn less than RM1,500 per month are considered as the vulnerable group who are struggling to make their businesses survive.

More than half of the respondents carry out trading business activities such as buying and selling, being distributors, or vendors. Meanwhile, 25 per cent of them run service related business activities such as tailoring, catering, operating a laundry, or a massage centre. Another 17.4 per cent are involved in manufacturing activities either in food processing or furniture making. Only a small number of them are engaged in agriculture as the survey was conducted in the urban area.

It was also found that a majority of them are self-financed ( 82.2 per cent), followed by borrowing from family and friends (23.6 per cent), and from banks and microfinance institutions (12.2 per cent). A small number of microenterprises (4 per cent) received loans from informal money lenders or "loan sharks" to finance their businesses because here, applying and approvals of fund are easy and very quick. However, these informal lenders are usually operating outside the legal provision of lending and offer clients loans of various amounts at exorbitant interest rates.

\subsection{Challenges and Expectations of Microentrepreneurs}

Microentrepreneurs face several challenges (Table 3). They face difficulties in penetrating the market, promoting their products, and being competitive with other established entrepreneurs. This is also due to their small capital. They need more capital in order to stay competitive in the market as well as for the expansion of the business. They also need other services such as access to market information, assistance in improving their products in terms of packaging and branding, technical assistance for better product quality, etc.

Table 3. Challenges and Expectations of the sample microentrepreneurs

\begin{tabular}{cccc}
\hline & Business Status & No of Respondents & $(\%)$ \\
\hline Challenges of Business & Demand for products & 348 & 23.2 \\
& Capital & 340 & 22.7 \\
& Competition & 333 & 22.2 \\
& Workers & 246 & 16.4 \\
& Skill & 132 & 8.8 \\
Support from government & 61 & 4.1 \\
& Support from family & 26 & 1.7 \\
& Other (Specify) & 13 & 0.9 \\
& Capital & 317 & 39.1 \\
& Access to market service & 126 & 15.6
\end{tabular}




\begin{tabular}{cccc} 
& Aid to improve product & 87 & 10.7 \\
& Training and technical assistance & 85 & 10.5 \\
& Assistance development & 53 & 6.5 \\
Financial literacy and education & Other (Specify) & 52 & 0.1 \\
Future Plan & Expand the business & 3 & 63.7 \\
& Change business & 359 & 4.6 \\
& Change location & 26 & 4.1 \\
& Shut Down business & 23 & 2.3 \\
& No plan & 13 & 25.3 \\
\hline
\end{tabular}

In spite of the several challenges, most entrepreneurs (63.7 per cent) are very optimistic and they plan to expand their businesses (Table 3). About a quarter of them are contented with what they are doing as they do not plan to do anything extra in the very near future. Around 11 per cent of the respondents are struggling and would like to shift or shut down the business.

Table 4. Perception of microentrepreneurs about microfinance borrowing

\begin{tabular}{|c|c|c|c|c|c|c|c|}
\hline \multirow{2}{*}{\multicolumn{2}{|c|}{$\begin{array}{c}\text { Perception of } \\
\text { Microentrepreneurs }\end{array}$}} & Strongly Agree & Agree & Neutral & Disagree & Strongly Disagree & Mean \\
\hline & & \multicolumn{6}{|c|}{ Frequencies (\%) } \\
\hline \multirow{6}{*}{$\begin{array}{c}\text { Microfinance } \\
\text { Non-borrowers }\end{array}$} & \multirow[t]{2}{*}{ Afraid to have debt } & 132 & 202 & 94 & 47 & 9 & \multirow{2}{*}{3.83} \\
\hline & & $27 \%$ & $42 \%$ & $19 \%$ & $10 \%$ & $2 \%$ & \\
\hline & \multirow[t]{2}{*}{ No need for credit } & 54 & 143 & 183 & 90 & 14 & \multirow{2}{*}{3.28} \\
\hline & & $11 \%$ & $30 \%$ & $38 \%$ & $19 \%$ & $3 \%$ & \\
\hline & \multirow{2}{*}{$\begin{array}{c}\text { Business is too weak to } \\
\text { run a credit }\end{array}$} & 27 & 129 & 183 & 108 & 37 & \multirow{2}{*}{3} \\
\hline & & $6 \%$ & $27 \%$ & $38 \%$ & $22 \%$ & $8 \%$ & \\
\hline \multirow{4}{*}{$\begin{array}{c}\text { Microfinance } \\
\text { Borrowers }\end{array}$} & \multirow{2}{*}{$\begin{array}{c}\text { The current loan is not } \\
\text { adequate }\end{array}$} & 3 & 29 & 23 & 11 & 1 & \multirow{2}{*}{3.34} \\
\hline & & $5 \%$ & $43 \%$ & $35 \%$ & $16 \%$ & $1 \%$ & \\
\hline & \multirow{2}{*}{$\begin{array}{l}\text { Have the ability to pay } \\
\text { back on time }\end{array}$} & 12 & 41 & 12 & 2 & 0 & \multirow{2}{*}{3.94} \\
\hline & & $19 \%$ & $61 \%$ & $17 \%$ & $4 \%$ & $0 \%$ & \\
\hline
\end{tabular}

Most of the microfinance non-recipients (mean 3.83) agreed that they did not borrow credit because they are afraid to become indebted. In addition, a majority of them (mean 3.28) believe that they do not need the credit. However, only 32 per cent agreed that their businesses are too weak to accomodate credit. Moreover, among the microfinance recipients, only 17 per cent mentioned that their current size of credit is enough, which means that the rest of the microentreneurs still have scope to take more credit. Among the current borrowers, only 3.7 per cent do not have the ability to pay back the credit on time, which means that most of them are competent with the ability to repay the credit.

\subsection{Estimation of Potential Market Size}

The Central Bank of Malaysia (Bank Negara Malaysia) has a provision for small business loans of up to RM50,000 (USD15,800) for business activities by microenterprises (Bank Negara Malaysia Annual Report, 2012). According to the records of the Department of Statistics, the number of total registered SMEs in Selangor is 125,904 and out of that, 74.4 per cent or 93,673 are microenterprises (National SME Development Council, 2013).

Our survey result shows that 76 per cent of the microenterprises are registered (Table 5). Therefore, the estimated total microenterprises would be $(93,673 / 76$ per cent $)=123,254$. Among the total microenterprises, 50 per cent have potential for microfinance loan (Gazy, 2005; Ayayi \& Yusupov, 2012); therefore, the total potential microenterprises are 61,627. Among them, 9.5 per cent already receive microfinance; thus, the rest are potential clients at around 55,772 microenterprises.

Table 5. Estimation of market size for microfinance in Selangor, Malaysia 


\begin{tabular}{cccccc}
\hline & $\begin{array}{c}\text { Registered } \\
\text { SME }\end{array}$ & $\begin{array}{c}\text { Registered } \\
\text { Microenterprise }\end{array}$ & $\begin{array}{c}\text { Estimated Total } \\
\text { Microenterprise }\end{array}$ & $\begin{array}{c}\text { Estimated } \\
\text { Total } \\
\text { Borrowers }\end{array}$ & $\begin{array}{c}\text { Estimated } \\
\text { Potential } \\
\text { Borrowers }\end{array}$ \\
\hline Considering Unregistered as 24\% & 125,904 & 93,673 & 123,253 & 61,627 & 55,772 \\
Considering Unregistered as 1/3 or 33\% & 125,904 & 93,673 & 283,856 & 141,928 & 128,445 \\
Considering Unregistered as 3/4 or 75\% & 125,904 & 93,673 & 124,897 & 62,448 & 56,516 \\
\hline
\end{tabular}

Estimation by the World Bank indicates that among all of the establishments, informal are between $1 / 3$ to $3 / 4$ (Nawai \& Shariff, 2011). Based on this assumption, here the estimated potential microenterprises would be 124,897 to 283,856 (33.3 per cent to 75 per cent of 93,673) (Table 5). Among the total microenterprises, 50 per cent have potential for microfinance loan (Gazy, 2005; Ayayi \& Yusupov, 2012); therefore, total potential microenterprises are 62,448 to 141,928 . Among them, 9.5 per cent already receive microfinance, which means that potential clients are around 56,516 to 128,445 microenterprises in Selangor, Malaysia.

\section{Conclusions and Recommendations}

The study found that only 9.5 per cent of the microenterprises received microfinance credits in Selangor, Malaysia, therefore a vast proportion of microentrepreneurs in Malaysia still have potential to receive microfinance credit. The estimated size of the potential microenterprises varies based on different assumptions. Overall, the range of the potential market size for microfinance is 55,000-128,000 microenterprises in Selangor, Malaysia.

There are several reasons for the small number of microfinance borrowers among the microenterprises. Most of the microentrepreneurs only rely on self-financing or financing from family and friends. Many of the entrepreneurs are part-timers who already have some sort of savings or have been saving for the expansion of their businesses. Some of them seek help from relatives, friends, or neighbours because they would expect them to return the favour sometime in the future, as a gesture of a reciprocal obligation. Moreover, most of them do not want to be involved with credit and be trapped in the cycle of interest. Further, many of them feel that the frequent loan payment is too burdensome because most of the microfinance institutions require a weekly repayment, while in the case of family members or friends, immediate repayment is not needed. They also lack confidence in growing their business and think that their businesses are not strong enough; therefore, they fear that they might lose what they have now.

Overall, most of the microentrepreneurs had negative perceptions about the loans though they agreed that Shariah compliant products are easily available in the market, and they have to change in order to progress with more capital. Therefore, the MFIs must take initiatives to promote microfinance among the potential microentrepreneurs so that they can maximize their outreach among the existing microentrepreneurs.

\section{Acknowledgement}

We would like to thank Asian Institute of Finance (AIF) in providing the financial support for this research project (Private Grant \# 402023130001).

\section{References}

Alam, M. M., \& Molla, R. I. (2012a). The Limitations of Microcredit for Promoting Microenterprises in Bangladesh. Economic Annals, 57(192), 41-53. Retrieved from http://ea.ekof.bg.ac.rs/pdf/192/138.pdf

Alam, M. M., \& Molla, R. I. (2012b). Inside Productivity of Microcredit in Bangladesh: A Surgical Analysis. Asian Economic and Financial Review, 2(3), 478-490. Retrieved from http://www.aessweb.com/ download.php?id=1405

Alam, M. M., Said, J., \& Hassan, S. (2015). Performance of Islamic Microcredit in Terms of Maqasid Al-Shariah: Case Study on Amanah Ikhtiar Malaysia. Humanomics, 31(4). 374-384. Retrieved from http://dx.doi.org/10.1108/H-12-2014-0072

Anand, M., \& Rosenberg, R. (2008). Are We Overestimating Demand for Microloans? No. 9521, The World Bank. Retrieved from http://hdl.handle.net/10986/9521

Ayayi, A. G., \& Yusupov, N. (2012). A methodology for the assessment of potential demand and optimal supply of entrepreneurial microcredit. Review of Development Finance, 2(2), 84-92. Retrieved from http://dx.doi.org/10.1016/j.rdf. 2012.05.003

Bank Negara Malaysia (BNM). (2012). Comparative Table on Microfinance Product Features. Retrieved from 
http://www.bankinginfo.com.my/_system/media/downloadables/simplified_microfinance_product_features _9fis_comparative_table.pdf

Cheng, E. (2007). The demand for microcredit as a determinant for microfinance outreach-evidence from china. Savings and Development, 31(3), 307-334. Retrieved from http://citeseerx.ist.psu.edu/viewdoc/summary? doi=10.1.1.522.6889

Dar, H., Rahman, R., Kamal, A. A., \& Malik, R. (Eds.). (2012). Global Islamic Finance Report. Park Royal, London: Edbiz Consulting Limited.

Gazy, A., \& Giuliodori, M. (2005). Microfinance in Brazil: An extensive evaluation of the sector (Unpublished thesis). Faculty of Economics and Econometrics, University of Amsterdam. Retrieved from http://dare.uva.nl/cgi/arno/show.cgi?fid=18067

Kamaluddin, A., Hadi, N. A., Alam, M. M., \& Adil, M. A. M. (2015). The Social Collateral Model in Perspective of Islamic Microfinance. Journal of Developing Areas, 49(5), 353-363. Retrieved from https://muse.jhu. edu/login?auth=0\&type=summary\&url=/journals/journal_of_developing_areas/v049/49.5.kamaluddin.html

Molla, R. I., \& Alam, M. M. (2008). A Reflection on Economics of Microcredit Borrowing in Rural Bangladesh. Journal of Business and Behavioral Science, 18(1), 227-241.

Molla, R. I., \& Alam, M. M. (2011). Microcredit - A More Credible Social than Economic Program in Bangladesh. Economics Bulletin, 31(2), 1095-1104. Retrieved from http://www.accessecon.com/Pubs/EB/ 2011/Volume31/EB-11-V31-I2-P102.pdf

Molla, R. I., Alam, M. M., \& Wahid, A. N. M. (2008). Questioning Bangladesh's Microcredit. Challenge: the Magazine of Economic Affairs, 51(6), 113-121. Retrieved from http://dx.doi.org/10.2753/0577-5132510608

National SME Development Council. (2013). SME Annual Report 2012/13. Retrieved from http://www.smecorp. gov.my/vn2/node/717

Nawai, N., \& Shariff, M. N. M. (2011). The Importance of Micro Financing to the Microenterprises Development in Malaysia's Experience. Asian Social Science, 7(12), 226. Retrieved from http://dx.doi.org/10.5539/ass.v7 n12p226

Osotimehin, K., \& Akinlabi, B. H. M. (2011). Determinants of microfinance outreach in South-Western Nigeria: An empirical analysis. International Journal of Management and Business Studies, 1(1), 1-7. Retrieved from http://internationalscholarsjournals.org/download.php?id=760908652711576847.pdf

Reinke, J. (2004). Demand Studies and How Not To Do Them: A Story About Pancakes (With Lessons From Microfinance) (p. 2). Retrieved from http://www.ruralfinance.org/fileadmin/templates/rflc/documents/ Demand_studies_pdf.pdf

\section{Copyrights}

Copyright for this article is retained by the author(s), with first publication rights granted to the journal.

This is an open-access article distributed under the terms and conditions of the Creative Commons Attribution license (http://creativecommons.org/licenses/by/3.0/) 